\section{EPITHETS REFERRING TO CHARACTERS IN THAI POETIC WORKS}

\section{Warawat Sriyabhaya ${ }^{1}$}

\begin{abstract}
This article is a study to classify the epithets referring to the characters in four Thai poetic works. The study results revealed that there are two groups of epithets to be found. The first one is epithets to praise characters by referring to their valuable entities, their dignity and their beauty. The second one is epithets to inveigh against characters. These epithets focus on the characters' ethnicity, negative characteristics, ugly physical appearance, and worthless elements. The use of epithets is the poet's strategy to express meaning and emotion in their poetic works. Moreover, the use of epithets through various words makes the literature more colorful and enhances emotional feelings in the readers.
\end{abstract}

\section{Introduction}

One of the aims of Thai literature is to entertain readers. According to Raksamani (2007: 633), literature is a work of art created from a poet's emotions, which allows poets to express their emotions through their works and encourages readers to share the same emotions. There are many techniques that poets employ to express their emotions or feelings through their works. One important technique which can precisely convey the poet's emotions to the audience is an epithet, a

\footnotetext{
${ }^{1}$ Lecturer, School of Liberal Arts, University of Phayao, Thailand
}

nominal phrase used to point out the important characteristics of characters such as their physical appearance, behavior and ethnicity, or to show if the character are praising or inveighing against someone. In this article, the epithets referring to characters are analyzed to investigate the emotions and feelings of the characters, and their creators, the poets.

As far as data collection and data analysis are concerned, the selection of Thai literature for this study was based on the following characteristics: narrative discourses or folktales with two characteristics: contingent temporal succession and agent orientation (Longacre, 1983), literary works with an exact written date and time, based on History of Thai Literature (Na Nakhon, 2002), main protagonists, who can be human or nonhuman; literary masterpieces of the Early Ayutthaya Era, the Thonburi Era and the Ratanakosin Era with these mentioned characteristics. The selected Thai poetic literature with the above characteristics are as follows: Lilit Phralo (the Early Ayutthaya Era), Sumutthakhot Khamchan (the Middle Ayutthaya Era), Lilit Phetmongkut (the Thonburi Era) and Khun Chang-Khun Phaen (the Ratanakosin Era).

In accordance with Halliday and Hasan (1976), the references were classified into three types: 1) Personal References: personal pronouns, possessive determiners and possessive pronouns 2) Demonstrative References: this, that, these, those, here, there, now, there. 3) Comparative References: same, such, similar, other different else, so-, as-, equally-, more, fewer, less etc.

Based on the framework of Halliday and Hasan, this study focused on personal references which were divided into three types. The first one was the personal 
pronoun including the first person, the second person and the third person pronouns. Another type was zero terms. The last type consisted of kinship terms, occupation terms, proper terms, epithets, etc. However, the only epithets to be studied in this paper had to be obviously found; furthermore, according to Chanawassa (1986) and Burusphat (1994), the epithets had to become one of the major language forms to contribute the poets expressing the characters' emotion appropriately and two enhancing the aesthetic value of their work.

\section{Types of Epithet Referring to Characters in the Four Thai Poetic works}

There were two main types of epithet referring to characters in the four literary works. They were the epithets used to praise characters and to inveigh against them.

\section{The epithets to praise characters}

The epithets to praise characters were found in three different types, namely, epithets referring to characters' valuable qualities, dignity and beauty.

The epithets referring to the characters' valuable qualities were pronouns denoting valuable qualities both concrete and abstract items such as jewels, money, loved ones, goodness, etc., as shown in the excerpt from Lilit Phralo below. The epithets were used to introduce the two main characters, Phraphuen and Phraphaeng.

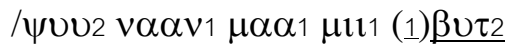

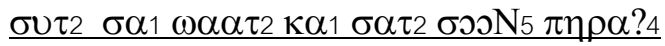

?oN1

$\sigma o \mathrm{~N}_{1} \chi \eta_{0} \mu_{5} \chi \alpha \nu_{1} \mathrm{~N}_{\alpha} \alpha \mu_{1} \mathrm{Ni}_{\alpha \nu_{3}}$ $\chi \eta \ddot{i 3} 3$ (2) $\tau \eta \alpha \alpha \omega 4 \pi \eta \dot{i} \alpha v_{3} \tau \eta \alpha \alpha \omega 4 \pi \eta \mathrm{EEN}_{1}$

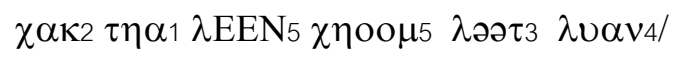

(Lilit Phralo 2002: 388, 392)

In the excerpt above, "(2) thaaw4 phian3 thaaw4 phesn1" or Phraphuen and Phraphaeng are called "(1)but2 sut2 sa1 waat2 ka1 sat2 soon5 phra?4 Poy1" (the two beloved daughters of the king.) This pronoun implies that Phraphuen and Phraphaeng are being praised because they are very important to the King, their father.

Some examples of the epithets are found in Samutthakhot Khumchan, Lilit Phetmongkut, and Khun Chang-Khun Phaen, respectively:

/paay1 nan4 (1)phrai4 sa1 mut2 khran4 fan1... dooy1 cay1 (2)luuk3 keEW3 klooy1 sa1 moon5... dooy1 (3) phra?4 luuk3 keعw3 ka1 sat2 trii1/ (Sumutthakhot Khamchan 2007: 133)

In the example, “(2) luuk3 keعw3 klooy1 sa1 moon 5" (my beloved son), and "(1) phrai4 luuk3 keEw3 ka1 sat2 trii1" (my precious jewel prince) refer to "(1) phra24 sa1 mut2" or Pharsamutthakhot who is the protagonist. These pronouns imply that Pharsamutthakhot's father, who is the King, praises his son as his valuable possession.

/(1)?on1 phra?4 phet4 mon1 kut2 choom5 chəət2 soo5 phon1...

chom1 choom5 (2) nos2 ka1 sat2 saan3 ... khuan1 pen1 (3) pin2 look3 lam4 loət4 ka1 sat2/ 
(Lilit Phetmongkut 2001: 155-156)

In the excerpt from Lilit Phetmongkut, "(2) noo2 ka1 sat2 saay3" (the crown prince) and "(3) pin2 look3 lam4 loət4 ka1 sat2" (the greatest king) refer to "(1) phra24 sa1 mut2" or Phraphetmongkut.

/pen1 laan1 yay2 kuu2 koэj3 nay1 hosj3 rian1

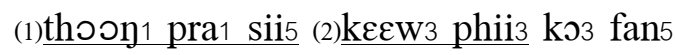
raay4

cin1 klecy3 tham1 naay1 sia5 pon2 pian3

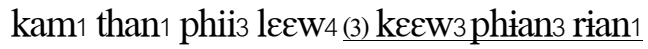
caw3 nap4 wan1 lecw4 ca?2 lian3 pen1 pii1 pay1/

(Khun Chang-Khun Phaen 2002: 26)

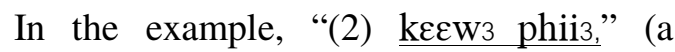
precious diamond), and "(3) keعw3 phian 3 rian1," (the valuable jewels in the house) are used to refer to "(1) thoon 1 pra1 sii s" or Thongprasri when Khun Krai, Khun Phaen's father, expressed his admiration to her because of his coming death.

The examples above obviously indicated that the language forms showing the characters' valuable qualities are pronouns referring to both concrete and abstract things. The concrete ones mentioned are diamonds, precious stones, silver, gold, gold ornaments and beloved persons as well. The abstract ones refer to goodness, beauty and neatness.

Another type of the epithet praising the characters are those referring to the characters' dignity. We can see some examples of them in the excerpts from Lilit Phralo, Sumutthakhot Khamchan,
Lilit Phetmongkut and Khun Chan-Khum Phaen, respectively.

/soon5 raat3 khuan1 (1)thaaw4 thay4 thi4 raat3 phuu 3 mii 1 bun $1 . .$.

yoo1 yot4 soon5 2oon2 thaaw4 liim 1 thua3 thuk4 decn1 daaw3

(2)los1 raat3 day3 fay1 saan5...fay 1 saan5

sooj5 num2 naa3

(3) coom1 raat3 khuan1 khit4 ?aa3

2a1 khraaw4 hua5 cay1 than3 naa1... thaaw4 tha?4 cam1 noon1 khlooy1 ?aay3

khloon1 (4)bos1 phit4 caw3 chan4

chii3 theع4 day1 thiam1 thiap3 naa1/

(Lilit Phralo 2002: 393-394)

In the above excerpt, "(1)thaaw4 thay4 thi4 raat3 phuu3 mii1 bun1" (the mighty king), “(3)coom 1 raat 3 " (the greatest king), and "(4)boos phit4 caw3 chan4" (the owner of the elephants, great animals which serve as the king's carrier) are different epithets to honor "(2) los1 raat3" or Phralo

/Raa3 (1)thaaw4 phuu3 soy1 rit4 thi1 braa1 krom3

kiat2 saay5 sa1 decy 1 dee 1 choo 1 cha1 yaa1 sit2 thi?4

sa1 yecn1 ?a1 rin1 raat3 thuk4 phaay1 ...

(2) caw3 nan4 mii1 choom5 khì1 ca?2 pr a1 $\operatorname{loom}_{1 /}$

(Sumutthakhot Khamchan 2007: 170)

In the excerpt, "(1)thaaw4 phuu3 son1 rit4

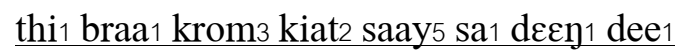


choo1 cha1 yaa1 sit2 thi 24 sa 1 yecn 1 ?a1 rin 1 raat3 thuk4 phaay1 (the mighty king with power and honor, fearful to enemies) refer to "(2) caw3" or King Rommayaburi.

/naam1 (1) thaaw4 rat4 na1 rim $_{1}$ beet $2 \ldots$

mii1 ma1 hee5 sii5 ləət3 lak4 chii3 pra1 $p$ haa 1 phak4 phen 1 phaan 1 ...

tha1 waay5 dec2 soon5 (2)thaaw4 thay4 thi 1 raat3 riay 4 thoo1 ra1 nii $1 /$

(Litit Phetmongkut 2001: 154, 164)

In the example, (2) "thaaw4 thay4 thi 1 raat3 rian4 thoo1 ra1 nii1" (the powerful king of this land) refer to "(1) thaaw4 rat4 na1 ri1 beet2...pra1 phaa1 phak4" or King Ratnarubet and King Praphaphak.

/ca?2 klaaw2 thin5 (1)phra?4 caw3 chian may2...

ca?2 klaaw2 thin5 (2)phra?4 Pon1 phuu son 1 phop4

loət3 lop4 phoo1 khay1 ma1 hay5 sa1 wan $5 . .$.

rak4 saa5 (3)phra1 2on1 phuu3 son1 tham1 khoo5 dee1 cha?4 nay1 saan5 waa3 (4)Son1 deet2

khroon 1 ni 1 weet 3 chiaj 1 may2 ma1 hay 5 $\underline{\text { sa1 wan } 5}$

tay3 yuu2 nay1 sat2 sut2 ca1 rit2 than1/ (Khun Chang-Khun Phaen 2002: 589, 593, 395)

In the excerpt, "(2) phra?4 Pon1 phuu3 son1 phop4 ləət3 lop4 phoo1 khay1 ma1 hay5 sa1 wuan5" (the greatest ruler), "(3) phra1 ?on1 phuu 3 soy 1 tham 1 " (the righteous king) and "(4) son1 deet2 khroon1 ni1 weet3 chiay 1 may2 ma1 hay5 sa1 wan5" (the powerful King of Chiang Mai) refer to "(1) phra? 4 caw3 chian1 may2" or The King of Chiang Mai.

In brief, the language forms showing the characters' dignity are pronouns meaning having dignity and fame or referring to wealth, greatness and bravery. These language forms, used as epithets referring to the characters in Thai poetic works, contribute to increasing the aesthetic value of the works.

The third type of epithet to praise the characters was those referring to the characters' beauty. Examples of these epithets were indicated in the following excerpts from the four works of Thai poetic literature.

/dian1 ca1 rat2 pha1 yoom1 ceem2 faa4 phi?2 bооу1 day3 hen5 naa3 (1) loo1 raat3 say4 duu1 (2)dian1 dut2 lec1... thuk4 mian1 mii1 luuk3 thaaw4 nap4 mii1 maak3 naa1 boo1 priap2 sooy5 ka1 sat2 trii1 phii3 noon 4

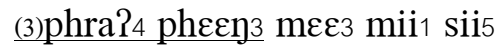
sa1 wat2 yin3 kha1 na1 naa1 (4)phra?4 phian1 choom5 yoy1 yooy4 yuu2 phian 4 (5) duan1 dian1/ (Lilit Phralo 2002: 389, 393)

In the above excerpt, "(2) dian1" (the moon) refer to "(1) loo1 raat 3 " or Phralo in order to praise his handsomeness. 
Moreover, "(5) duan1 dian1" (the full bright moon) refers to "(3) phra24 phecn33" or Phra Phaeng and "(4) phra?4 phian1" or Phra Pheun due to their beauty.

/Raa2 (1) mec2 phuu3 mii1 naa2 khij1 sa1 $\underline{\text { si? } 2} 2$ Pan 1 rian 1 chaay $5 . .$.

soy1 naam1 koon1 bos2 woon1

(2)phin 1 thum 1 ma1 dii 1 Ran 1 choom 5 cha1 law5/

(Sumutthakhot Khamchan 2007: 168, 170)

In the example, "(1) meع2 phuus mii 1 naa2 khii1 sa1 siP2 Pan1 rian1 chaay5" (the woman who is like a shining moon) refers to "phin1 thum1 ma1 dii1" or Phinthummadi.

/(1) naan1 khray3 chit4 chom1 thay4... phra?4 ni1 yom1 kham1 phii2 liay4 day2 day3

(2) nut4 nia4 klian 3

neعр3 khlaw4 khlin1 chəəу1/

(Litit Phetmongkut 2001: 181)

In the above excerpt, (2) "nut4 nia4 kliaj3 3 " (a woman with fair complexion) refer to "naay1" or Pathummawadi.

/Ra1 nit4 caa1 keعw3 taa1 khooy5 phii3 Рәəу5

kra1 ray1 ləəy1 duan3 khap2 sia5 yаay3 yаaуз

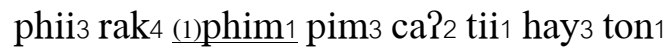
taay 1

phin3 wen4 waay1 wan1 nii4 day3 phop4 nวoy $4 \ldots$ (2)naam1 pliim3 meع3 ca?2 liim1 lon1 thuk4 wan1

saa5 ra1 phan1 ruan1 ree1 ca?2 hee 5 haan2

(3)caw3 yaam1 plost2 yoot3 rak4 khoon 5 phlaay1 kecw3

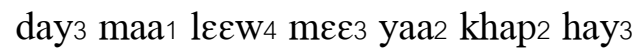
klap2 niis/

(Khun Chang-Khun Phaen 2002: 89, 97)

In the above example, “(2) yaam1 plitm3” (a very attractive woman), and "(3) caw3 yaam1 ploot2 yoot3 rak4 khoon 5 phlaay 1 kع\&W3" (Phlai Keaw's perfectly beautiful woman) refers to "(1) phim1" or Phim.

In the above examples, the language forms referring to beauty are pronouns indicating both male and female characters' good works. These epithets imply praise of the characters and enhance the literary works' aesthetic qualities.

In the study, it was found that many epithets referring to the main characters in the four literary works were used to praise the characters because of their value, dignity and beauty and strengthened the works' aesthetic qualities. Furthermore, another type of epithet which contributed the works' value was those inveighing against the characters. They are shown in the following section.

\section{Epithets inveighing against the characters}

The second major type of epithet found in the study were epithets inveighing against the character. However, a detailed study of the four literary works indicated that 
there was no invective in Lilit Phralo, Lilit Phetmongkut and Samutthakhot Khamchan because all of them were about the royal court and the royal families so, any impoliteness was prohibited. As a result, only Khun Chang-Khun Phaen, which is about ordinary people's lives in which people are able naturally to express their anger with invective, displayed many epithets inveighing against the characters. In the study of epithets inveighing against the characters, four different types were found, namely, epithets focusing on the characters' ethnicity, their negative characteristics, their ugly physical appearance and worthless things or animals.

The characters' ethnicity was used in epithets inveighing against the characters because some ethnicities which are presented in Khun Chang-Khun Phaen are not powerful and were not admired by other ethnic groups. We can see some examples of these epithets in the following excerpts.

/faay2 waa3 nuan1 naay1 sii5 maa1 laa1

khiin1 nan4 nit4 thraa1 koo3 fay2 fan5

waa3 loy1 sa?2 len3 naam4 sam5 raan1

khran1

hen5 but1 sa1 ban1 dosk2 nin2 duu1 phin1taa1...

pluk2 (1)iii1 məəy4 keع3 fan5 wan2 Raa1 rom1

Pii 1 məəy 4 chom 1 waas fan 5 khøon5 naay 1 dii1...

sii5 maa1 laa1 waa3 wəəy3 (2) Rii1 mosn1 thosy2

Raw1 phua5 phээyз maa1 phuut3 may3 pen1

phon5

nii3 leع1 san5 chaat3 phray3 thii3 nay5 mii1 sen3 phii5 nay1 mun4 (3)moวn1 can1 ray1... phra?4 phi1 cit2 waa3 duu1 (4)iii1 moon1 thooy2 sak2 n๖๖2 ?oэn2 ca?2 ləəy1 pen1 klaak1 klian3

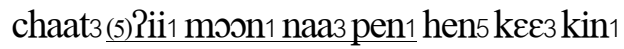
naam4 kha1 min3 may3 ?aw1 pay1 hay3 yost2 taa $1 /$

(Khun Chang-Khun Phaen 2002: 632, $367,646,654)$

In the excerpt, Srimala inveighs against her servant, "(1)?ii1 məəy4" or I-Mei, who is Mon, by addressing her as "(2) ?iii moon1 thooy2" and "(3) moon1 can1 ray1" (damned Mon) and "(5) ?iii moon1 naa3 pen1" (a funny faced Mon).

/(1) sosy3 faa4 tua1 san2 Puu2 yan1 jok4 hok2 peqn3 tooy2 kra1 tha?4 phla?2 khaw3rian1 thooy1 pra1 siis rooy4 waa3 (2) 2ii1 haa2 laaw1 tham 1 chaaw5 ciaw1 2 ii 1 maa5 khii rianspian3 thee1 pecn3 klecn3 hay3 pro?2 lə?4 than4 rian1 kra1 tha?4 kra1 thøу3 tooy2 klian3 (3)laaw1 can1 ray1...

kec1 pəət2 naa4 taan2 mosy4 maa1 roon4 waa3 pay1

tam1 raa1 Ra1 ray1 (4) 2001 sosy3 faa4

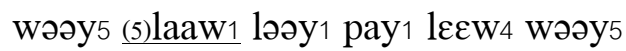
¡દeз Đəon1 kra1 ray1 ləəy1 pen1 nak2 naa5...

thaan 3 уаaз waa3 mee2 maa1 priap2 prəəy1 wəəy5 (6)?ii1 laaw1 paa2 paak2 khəэ1 man1 nak2 nak4

kos3 phra?4 min1 ?in3 chaaw5 (7)?ii1 laaw1 loon1...

roon 4 ta1 koon1 kəon3 baan3 Pii1 khaan1 hak2 Rii1 cet2 roy4 4 maa5 yiaw3 bia2 man1 lia5 rak4 
tham 1 hik4 hak4 mii3 chaaw5 $(8)$ iii 1 laaw1doon1

thooy1 pra1 sii5 daa2 chaaw5 (9)?ii1 laaw1don1 maa1 phect2 son2 sian5 roon4 уuu2 саa3 саaз̣/ (Khun Chang-Khum Phaen 2002: 970, 910, 916)

In the second example, "(2) ?ii1 haa2 laaw1" and "(3) laaw1 can1 ray1" (a damned Laotian) refer to “(1) sooys faa4 (Soifa), another wife of Phra Wai) when Thongprasri, Pra Wai's grandmother, and Srimala, his chief wife, inveigh against Soifa. Moreover, "(5) laaw1 (a Laotian)", “(6)Rii1 laaw1 paa2," (a Laotian from the wilds), “(7) 2ii1 laaw1 loon1" (an extremely rude Laotian), “(8) $\underline{\text { iii } 1 \text { laaw1 }}$ doon 1 " (a Laotian from the mountains) and "Pii1 laaw1 don1" (a Laotian from the wilds) is used to refer to "(4) $\underline{\text { Pos1 }}$ sooys faa 4 " or Soifa.

The second type of epithet inveighing against the characters are epithets focusing on their bad characteristics including their badness, stubbornness and arrogance. Some epithets are shown in the following excerpts.

/duu1 duu5 pen1 day3 (1) Rii1 wan1 thoon1... (2) Rii 1 seen 5 thooy2 can 1 ray 1 cay 1 that min 1 day2 phet1 nin1 kəət2 khin3 nay1 Raa1 com1 ruup3 yaam1 naam1 phro?4 nээy3 pay1 rï5 cay1 may3 sii3 som5 sak2 thaw3 sen3 phom5 min1 niiз thəoу2 yij3 kwaa2 thəoу2 (3)?ii1 thaay4 mian $1 . .$.

kuu1 ca?2 haa5 mia1 hay2 yaa2 ?aa1 lay1 (4)yin5 kaa2 la1 ki2 nii1 2ii1 phect3 sa1 yaa5 man1 may3 naa3 chəəy1 chit4 phit4 sa1 may5/ (Khun Chang-Khun Phaen 2002: 865866)

In the excerpt, "(1)?ii1 wan1 thosn1" (Wanthong) is called "(2)Rii1 seen5 thooy2 can1 ray1 cay1 tha4 min1" (an extremely wicked and vicious woman), "(3) ?ii1 thaay4 mian1" (a woman from a whorehouse), and “(4) yin5 kaa2 la 1 ki2 nii1 1 2ii1 phect3 sa1 yaa5” (a whore) when King Phanwasa inveighs against her because she cannot decide if she would like to live with Khun Chang or Khun Phaen.

/(1)khun5 chaan4 khit4 waa3 mecs yaay1 daa2 faa4 phaa2 thəət2 chan 5 haa5 days thecy 1 may3 soy2 wan1 thoy1 maa1 chaa4 yuu2 yay1 sii5 pra1 can1 khat2 cay1 (2)?ay3 baa3 kaam1...

wan1 thoon1 roon4 ?in1 yuu2 nay1 hoon3 khun5 chaan4 khom2 heen5 noxy4 phos phlaay1 keEW3

(3)?aay3 haa2 man1 ca?2 khaa3 mia1 sia5 lecw4 huu 5 taa1 boon3 becw4 mian5 mecw1 khraaw1...

(4)?aay3 khii3 thosy2 thoуy5 pay1 hay3 phon 4 kuu1 hua5 huu5 mian5 luuk3 ma1 phraaw4 haaw3... muy4 phan1 wan1 thoon1 day1 khay2 phook3 kuu1 haay5 cay1 may3 ?ook2 (5)?aay3 chip2 haay5

(6)khun5 chaan4 khway2 khwaa4 nay1 taa1 laay1 muy 4 phan1 wun3 waay1 yuu2 sin3 thii1... 
rooy 4 con 1 taa1 plin3 din3 ca?2 luk4

kuu1 cuk2 khin3 maa1 lecw3 (7)?aay3 taay1

hoon5/

(Khun Chang-Khun Phaen 2002: 289-290)

In this excerpt, "(2) Pays baa3 kaamı" (a satyr), "(3) ?aays haa2” (a brutish man), “(4) ?aays khii thooy2" (a man of base actions), and "(7) Raays taay1 hoon5" (a demon) refer to "(1) and (6) khuns chaan4" (Khun Chang). These epithets are used to inveigh against Khun Chang by Wanthong and Sriprajan because he has told them that he would like to get married to Wanthong.

The characters' ugly physical appearance also serves as the third type of epithet to inveigh against the characters in Khun Chang-Khun Phaen. Some epithets are revealed in the following excerpts.

/doot2 loy1 phiin4 klaay1 thii3 khaay3 nay1 secy5 fay1 raay1 raay1 sa1 waan2 naa3 tat2 maan3 koon1 way4 lecw4 khlay1 khlaa1 pəot2 muy 4 hen5 naa3 (1)caw3 wan1 thoon1...

min1 yaam1 teع2 ruup3 cuup1 may3 həom5 (2) Rii1 naas mosm 1 kon3 mos3 2ii1 khos 1 hon5 thiip2 tok2 caak2 tiay1 khiay1 kan1 loy1 hay3 man1 khoy1 chii1 wit4 pay1 yay1 mii1/ (Khun Chang-Khun Phaen 2002: 294-295)

In the above excerpt, "(2) 2ii1 naas moom1 kon3 mos3 Rii1 khoo1 hon5" (an ugly woman with a black face and a long neck) refers to "(1) caw3 wan1 thoon11" (Wanthong). Khun Phaen uses it to call Wanthong, his wife, when he finds that Khun Chang had become her mistress. /faay2 (1)khun5 chaan4 nay3 yaw5 mays khaw3 klay3 rooy4 hay3 naa3 khaaw5 raaw1 khap2 phii5... (2) 2aay3 hua5 phuun 1 phom5 klians khin3 thian'4 pay1 thin 5 luuk3 thuun 1 muun 1 heet2 phon 5 ton3 plaay1... nay3 roon4 hay3 yia1 day1 ?aay3 chip4 haay5 (3)?aay3 chaat3 chuas huas laan4 ka1 baan1 $\underline{\text { laay1 }}$

khon1 ca?2 taay1 lecw4 yay1 son1 bon2 nin 1 thaa1...

(4)?aay3 chaat3 khaas huas laan4 pra1 caan 1 kuu1... day3 len3 kan1 Riik2 la?2 may3 ləəy1 la?4 phra?4 ca1 mïn2 way1 waa3 wәəy5 (5)?ay3 huas laan4...

Pii1 teع1 rę3 khaw3 khuan2 Paw1 khaay3 chiik2 (6)?aays hua5 laan4 maa1 2iik2 lecw4 khaa3 way3/ (Khun Chang-Khun Phaen 2002: 877878)

In this excerpt, “(2) ?aays hua5 phuun1 phom 5 kliay 3 " (a man with a big and bald head), "(3) ?aay3 chaat3 chuas hua5 laan4 ka1 baan1 laay1" (a damned bald man with a disease of the scalp), "(4) ?aays chaat3 khaas hua5 laan4" (a damned and bald man), and "(5) and (6)?aays hua5 laan4" (a bald man) refer to "(1) khun5 chaan4" or Khun Chang. All epithets mentioned express Khun Chang's extremely ugly appearance, especially his baldness.

The last type of the epithet inveighing against the characters are epithets which represent worthless things or animals. 
Some epithets are shown in the excerpts below.

/khraa1 nan4 naay1 phim1 nim3 sa1 nit2 kheen4 cit2 khat2 cay1 pen1 nak2 naa5

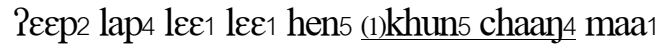
fecn5 faa5 fay 1 riay3 hay3 khiay 1 cay1... (2)dook1 təəy1 rï5 ca?2 ploom1 pha1 yəom1 phray1

maa5 ca12 kəət2 chin1 maa5 kəət2 min1 pay1 taay1 sia5 thəət2 (3)?aay3 haa3 bia3 naa3 taa 1 chen 3 nii4 ca?2 mii 1 mia1 (4)?aay3 ma1 muan3 maa5 lia1 may3 ciam1cay1 mian5 (5)ma1 lecy1 pos1 ?uat2 ?it2 waa3 rit4 sut2 ca?2 khecn2 khrut4 khaam3 ?aaw2 tha1 lee1 yay2 (6)koon3 saw3 rï5 ca?2 thaw3 meen1 kray1 (7)hin 5 hoуy 3 pray1 ca?2 khecy2 secn5 su1 ri1 yoy 1 chaat3 chua3 tua1 day1 (8)nok4 ta1 krum2 / (Khun Chang-Khun Phaen 2002: 124-125)

In the excerpt, "(2) dook1 toəy1" (Tei flower, a flower devoid of beauty), “(3) ?aаyз haas biaз” (five cents), “(4) Raays ma1 muanз maa5 lia1" (a mango licked by a dog),(5) ma1 lecn1 poo1" (a dragonfly), “(6) koon3 saw3” (a burned rock), "(7) hin5 hoэyз pray1" (a wild firefly), and "(8) nok4 ta1 krum2" (Takrum bird, an ugly bird like a vulture) represent Khun Chang when Wanthong inveighed against him because he has paid court to her. /chum1 phon1 kraap2 tiin1 phii3 sii5 maa1 laa1 mì1 1 chet4 naam4 taa 1 lecw4 hun 5 han5 maa1 thin5 (1)Sooy3 faa4 roon4_daa2 phlan1

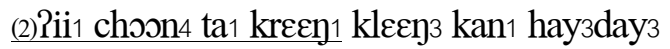
Paay $1 . .$. thoon1 pra1 sii5 fay1 waa3 naam4 taa1 tok2 (3)iii yaa1 cok2 khray1 tham 1 hay 1 min 1 nan $3 /$ (Khun Chang-Khun Phaen 2002: 10381039)

In this example, (1) sоэуз faa4" (Sroifa) is called "(2) Pii choon4 ta1 kreqn1" (a useless spoon), and "(3) Pii1 yaa1 cok2" (a poor and valueless woman) by Phlai Chumphon, Phrawai's son, when he finds that she has used a magical device to make Phrawai love her.

These language forms used the epithets to inveigh against the characters display some negative meanings such as, blaming, looking down upon or scorning. These epithets help to accentuate the beauty of the language in Thai poetic works.

\section{Conclusion}

In conclusion, it was found that the epithets of the characters in the four literary works were classified into two groups namely epithets praising the characters and the epithets inveighing against them. Praising was indicated with epithets referring to valuable entities, the character's dignity and their beauty. As for the invective, the epithets focused on the characters' ethnicity, their bad characteristics, their physical appearance and the worthless things. The epithets praising the characters were obviously employed in all four of the chosen pieces of literature but the epithets inveighing against the characters were stated, remarkably, only in Khun Chang-Khun Phaen. This is possibly because the other three literary works studied are about the royal families and it was improper to include impoliteness in the works, whereas, Khun Chang-Khun Phaen is a 
piece about the lives of laymen reflecting the way of life, language usage and beliefs of folks in that time. When, it was common for ordinary people to express their anger verbally by inveighing against each other. Overall, the two types of epithet obviously reveal the writing ability of the poets in employing literary language to express their meaning and emotion in an appropriate manner, thus enhancing the aesthetic value of their works.

\section{References}

Burusphat, Somsonge. 1994. Discourse Analysis. Nakhonpathom: Institute of Language and Culture for Rural Development, Mahidol University.

Chanawangsa, Wipah. 1986. Cohesion in Thai. Ph.D. Dissertation, Georgetown University.

Department of Fine Arts. 2001. Litit Phetmongkut. Bangkok: Department of Fine Arts.

---. 2002. Khun Chang-Khun Phaen. $19^{\text {nd }}$ ed. Bangkok: Bannakhan.

---. 2002. "Lilitphralo" In Thai Literary Work of the Ayutthaya Volome 2.

Bangkok: The Fine Arts Department.

---. 2007. "Samutthakhot khamchan" In Thai Literary Work of the Ayutthaya Volome 2. Bangkok: The Fine Arts Department.

Halliday, M.A.K. and R. Hasan. (1976). Cohesion in English. London: Longman.
Longacre, Robert E. 1983. The

Grammar of Discourse. New York:

Plenum Press.

Raksamani, Kusuma. 2007.

"Evolution in Essence and Idea of Thai Litreature." In Development of Thai Litreature. $7^{\text {th }}$ ed. Nonthaburi: Sukhothai Thammathirat Open University.

Na Nakhon, Pleung. 2002. History of Thai Litreature. Bangkok: Thaiwatthanaphanit. 